\title{
A Victim of Circumstance: \\ The Timber Bill of 1772 and the East India Company
}

Michael R. Snyder

ABSTRACT: In 1771 a bill was brought before the British Parliament to limit the ronnage of East India Company ships. The Admiral ry claimed thar construction of the large trading vessels consumed vital and dwindling supplies of English oak required by the Royal Navy. After convening for a year, the Committee organized to investigare the "timber" bill reported that the Company was not solely responsible for the shorrage of rimber. However, by 1772 the Company was in serious financial difficulty. In the face of mounting pressure for government control of the Company, the timber bill became another vehicle in the debate of whether the Crown or the Company should contral India. Although passed, the rimber bill had less to do with the merirs of preserving vital oak for the Royal Navy than it did with efforts to limit the powers of the East India Company.

There is presently a mass of literature on the East India Company and the events pertaining to the Regulating Act of $1773 .{ }^{\prime}$ Similarly, the years leading up to the critical events of the 1760 s, as well as Company affairs during and after 1784, have been examined in detail. ${ }^{2}$ Nonetheless, while the majority of these works deal with political or financial aspects of the Company, shipping and procurement issues have been a neglected topic. ${ }^{3}$ In an attempt to move away from a narrow fixation upon the more prominent bills of 1773 and 1784 this paper will focus on a new issue concerning the East India Company's shipping interests in the 1770 s. In addition, related issues dealing with attacks on the Company's autonomy will be examined.

On March 11, 1771, Mr. Buller brought a bill before the House of Commons that would limit the tonnage of the East India Company's ships. Seconded by Mr. Augustus Hervey, this was to be the start of a series of committee and Parliamentary debates which would stretch on for over a year. Buller and Hervey, both Lords of the Admiralty, initially viewed the bill only as a means of preserving vital supplies of timber for the Royal Navy. However, the bill was descined to become another facet in the struggle between the Directors of the Company and the Crown to determine who would hold sovereignty over not only the Company's troubled financial empire, but its territorial possessions in India. 
The bill, entitled "For the More Effectually Securing Sufficient Quantities of Oak Timber for the Use of the Royal Navy," complained that the "Tonnage of the Ships employed, and of those now building in order to be employed, in the Service of the United Company of Merchants of England trading to the East Indies, doth greatly exceed the Tonnage of Shipping requisite to carry on the Trade of the said Unired Company to and from the East Indies..." and called for the East India Company's shipping tonnage to be reduced from 60,000 to 45,000 tons. ${ }^{5}$ At the heart of the issue was the belief that the East India Company was unnecessarily consuming oak timber fit for the building of the large ships of the Royal Navy. Buller and Captain Constantine Phipps were the tellers for the yeas to bring in the bill, while Mr. Dempster and William Burke, cousin of the more renowned Edmund Burke, were the tellers for the noes. The vote was close, and the motion was carried by a margin of only three (53 to 50$)^{6}$. Mr. Stephens and Captain Phipps were then ordered to ensure that a "Committee be appointed, to consider how His Majesty's Navy may be better supplied with Timber; and to report the same, with their Opinion thereupon, to the House."

The bill represented a concerted effort by the Admiralty to limit the amount of timber used by the East India Company. This is readily apparent when one recognizes that Buller, Hervey, Stephens, and Phipps were all highly placed members of the Royal Navy (at this time, Stephens was the Secretary of the Admiralty, a position that Phipps, later Lord Mulgrave, would eventually hold). In opposition were those loyal to the Company such as William Burke who had a personal interest in the expansion of the Company. Both he and Richard Burke (Edmund's brother) had invested heavily in East India Company stock. ${ }^{8}$ Indeed, the two had been nearly ruined financially when Company stock plummeted in May of 1769. Now, only a strong and expanding East India Company could help return their fortunes. Burke thus made sure that he was on the Commitree which would investigate the timber issue.

The Committee was on neither a witch hunt against nor a crusade in favour of the East India Company. Certainly, individual Committee members would have had their personal views concerning the organization of the Company; however, first and foremost, the Committee was under the obligation to maintain the strength of the Royal Navy, without which Britain could not maintain its standing as a world power. What became apparent by the time the Committee presented its report to the House of Commons is that political priorities had changed. Opinions had shifted and lines were drawn so that there were only two camps: those who supported the East India Company's independence 
and those in favour of greater government control. The eventual passing of the timber bill in May 1772 had less to do with the merits of preserving the vital oak timber for the Royal Navy than it did with the financial and political difficulties plaguing the East India Company in the early 1770 s.

ii

The Committee, which met for close to a year, investigated four areas relating to the timber issue:

First, the State of Timber fit for the Supply of His Majesty's Navy, its Sufficiency or Insufficiency for that Purpose, secondly, in case of Insufficiency, to what Causes it might be imputed; thirdly, its Operation on the Prices, Fourthly, the Means of further Supply at Home, and by Importation; and under this Head, nacurally come the Nature and Quality of the different Sorts of Timber.?

While there was no denying that the Royal Navy was in dire straights with respect to the supply of timber, Committee members may have initially hoped that an easy solution to the timber problem would readily present itself. It quickly became apparent to all involved that this was not to be the case. The difficulties which plagued the Royal Navy had originated years earlier and could not be easily resolved.

At the end of the Seven Years War in 1763, the British Navy was the strongest in Europe, and all British departments wanted to maintain it as such. In the aftermath of the war George III presented a speech to the House of Commons in which, although he stressed frugality, he urged Parliament to continue to support the Navy, "the most constitutional force, and the best security for Great Britain ..." ${ }^{10}$ Despite Parliament's promise to maintain the Navy on "the most respectable footing", the Navy declined in strength. Many accused the Navy Board of misadministration, although this could not account for all of the Navy's difficulties. Rather, it appears that the greatest culprit was simply an underestimation of the costs required to maintain the Navy in a time when scarcity of materials was increasing operating costs. By the mid 1760s, the Fleet consisted of over 135 Ships of the Line totalling roughly 300,000 tons of shipping. " To repair fully all of the ships would have required an estimated 4,200 shipwrights. Gathering such a force proved impossible, and slowly the ships of the Royal Navy rotted away at anchor, waiting for repairs. Consequently, the cost to repair the Navy soared, requiring $£ 4,000,000$ between 1763 and 1770 in the form 
of Parliamentary grants. ${ }^{12}$ By 1770 the Royal Navy required far more than repairs. Construction of a huge number of new ships would have been necessary to maintain the Fleet at full strength. However, a new difficulty, never before encountered by Britain, had become apparent: a shortage of timber needed for the reconstruction of the Fleet.

England did not have the correct climate for the growing of the tall, straight trees required for masts, although the British Isles were ideally suited for the growing of the oak needed for the hulls of ships. However, the oak forests used to construct the great British fleets of the seventeenth and early eighteenth centuries were gone: "England's original ample heritage of oak ... was wasted and wise laws, which could easily have ensured an adequate naval supply were allowed to fall into neglect."13 The Commissioners of the Navy (the Navy Board) were responsible for the supply of naval timber. As R.G. Albion has commented, while the Board was "Composed chiefly of retired naval officers and dockyard officials, this department of state possessed more conservative common sense than energy or vision." 14 Consequently, while Lord Sandwich had complained of Royal Navy building practices as early as 1749 , nothing had been done to ensure an adequate supply of naval stores and twenty years later the crisis was at hand. ${ }^{15}$ The Committee formed in 1771 to investigate possible solutions to the timber shortage was aware that readily accessible British timber had been exhausted. They commented that "New Forest, and the Forest of Dean, are the only King's Forests which yield any considerable Supply for the Use of His Majesty's Navy ..."16 This "considerable Supply", though, was but a fraction of the total timber required. These forests only supplied between a tenth and a fifth of the wood consumed yearly at Portsmouth and Plymouth. The remainder of the timber was furnished through importation.

The difficulty with importing timber was three fold. First, English shipbuilders were convinced that "Foreign Timber is inferior in Quality" to British grown oak and were reluctant to use it (although they would, if there was no alternative, grudgingly use timber from Silesia and Danzig). ${ }^{17}$ The second problem was cost. The Baltics were the principle region from which to purchase masts and other naval stores. As long as a nation's credit was good, delivery of fine quality timber was assured. The Germans, Swedes, Poles, and Russians would not take enough English woollens and cutlery to pay for the timber, however, and the balance had to be paid in cash. ${ }^{18}$ With the substantial debt already incurred by the Navy, such payments for Baltic timber and naval stores were unpopular with the British Parliament, to say the least.

British North America could have circumvented this and provided sufficient timber and naval stores so that the British did not have to rely 
on the Baltics. Since the start of the Dutch War of the 1670s, when supply lines to the Baltics were almost completely cut off, the Royal Navy had turned to New England for a supply of masts, and between 1652 and 1775 many of the great masts were brought to the Navy yards from either Portsmouch, New Hampshire or Falmouth (now Portland), Maine. In addition, the Americans could have provided the British with tar, pitch, turpentine, hemp, and oak. A series of Parliamentary Acts were passed between 1705 and 1729 with the aim of encouraging the development of a large scale colonial naval stores industry." Liberal bounties were offered for naval stores, masts, and timber. As has already been mentioned, the Navy Board was rather traditional in its thinking, and found it easier to rely on the already well organized Baltic suppliers than to work seriously on the foundation of a similar operation in the American colonies. The result was that New England ended up selling masts not only to Britain, but, in defiance of laws specifically prohibiting such transactions, to France and Spain as well. The West Indies were also willing to pay premium prices for New England masts and timber. Consequently, while all pines over 24 inches in diameter were to be protected as potential masts for the Royal Navy, the Surveyor General of His Majesty's Woods in America was rarely able to enforce this regulation, and the trees marked with the Broad Arrow often ended up in shipyards other than those of the Royal Navy.

The third problem with importing the required timber, especially from the Baltics, was ensuring that clear lines of supply remained open. The British feared that the Baltics would fall under the control of the French or-Spanish. Much effort was exerted to ensure this did not happen: blockades and the boarding of rival ships by the British were carried out to prevent vital Baltic naval stores from reaching other European naval powers. Such seizures of foreign ships by the British infuriated the French and Spanish, as well as the Baltics, which were thus deprived of potential customers. This created uneasy European relations. ${ }^{20}$

Faced with these difficulties, the Committee suggested two possible options of providing more timber for the Royal Navy. First, they recommended that

[o]ne Expedient for supplying the Deficiency of Timber would be the Introduction of Foreign Timber in a larger Quantity than at present; and that the Navy Board are now actually treating for it from Hamburg, Stetin, HolLand, and America ....21

The Commitree also put out tenders for timber from other countries thar had nor previous ly served as suppliers: however the resnonse was 
poor. The second option the Committee arrived at was "advancing the Price of Carriage, to enable the Merchants to bring [timber] from the Inland Parts of the Country ..."22 The premise behind the second proposal was that while the readily accessible forests, that is, those within fifty miles of a naval shipyard, had been exhausted, there were sufficient quantities of timber to be had in the forests of the British interior. If the government would subsidize the cost of transportation, this timber could be brought to Portsmouth and Plymouth, the main Naval shipyards in England. The difficulty, of course, was the issue of subsidization. Both the importation of more timber and the harvesting of inland timber would be quite costly. Clearly, these recommendations would not solve the problem of insufficient timber for naval construction.

The Committee members, recognizing the complexiry of the problem of timber shortage as well as their own lack of experience concerning shipbuilding and timber procurement, sought the advice of a number of shipbuilders, suppliers of timber, and other experts to arrive at an explanation for the shortage of the timber. After consultation, the Committee reported that
the Scarcity of Timber is occasioned partly by building such a large Number of East India Ships, partly by the general Increase of Shipping, and in a considerable Degree by the Augmentation of the King's Ships, in their Number, their Size, and their Scantlings ... ${ }^{23}$

Between 1740 and 1770 the Royal Navy had been increasing steadily in size, not just in the number of ships in the fleet, but in the tonnage of the ships. In addition, as has already been mentioned, after several wars during this period, those ships that had survived were in serious need of repair. Nonetheless, it is unlikely that the Admiralty had expected to bear any of the responsibility for the timber shortage when it had proposed the bill to limit the construction of East India ships. As the Committee report demonstrates, however, the East India Company was not about to become the easy scapegoat for the timber shortage, although the Company did not emerge completely blameless, since the Committee noted that while there had been

a great Increase of Shipping in general; and Ships of all Dimensions interfere with the King's Ships of the like Dimensions, and the Price has been raised in Proportion upon all Timber, of the private shipping firms, the Increase has particularly been in the East India Company's Ships, which from 30 Sail, their Number 30 Years ago, 
are now 90 Sail, one of which Ships of 800 Ton would take the same Scantling as a Ship of War of 50 or 60 Guns. . . 24

The laying of blame by the shipbuilders interviewed by the Committee for the lack of imber depended largely on who employed their services. Mr. Wells, for example, a shipbuilder who had been employed by the Navy for years, reported that

the East India Ships were allowed to go but 4 Voyages, which are performed on an Average in 12 Years; consequently all 91 Ships are rebuilt within the Term of 12 Years [and] on breaking up the East India Ships, very little of their Timber is made Use of in Ship-building. ${ }^{25}$

The testimony of John Bernard, a private shipbuilder, can be viewed in contrast to that of Mr. Wells. Bernard maintained that because of the "vast Quanticy cut down for Ship-building, some for private Trade, but principally for the Navy" there was a shortage of timber. ${ }^{26}$

Although blaming either the East India Company or the Navy for the depletion of the supply of British timber was popular, there were other explanations brought before the Committee. Robert Fisher, another shipbuilder and a timber merchant, believed that the scarcity of timber was partially due to

the Conversion of Timber into Coopers Ware and orher small Sruff; insomuch, that nor One Fourth Part of the Timber fit for the Navy hath been applied to that Purpose; and another Cause is, the Conversion of Wood Lands into Arable. ${ }^{27}$

John Bernard also complained of a neglect of planting new forests. ${ }^{28}$ The oak planting policies of the early 1600 s had not been carried on through the seventeenth and eighteenth centuries. ${ }^{29}$ The result of only a few of the royal forests still providing timber was a transfer of the burden of oak supply onto the private groves. While the Committee agreed with Fisher that the scarcity of timber arose partially "from the Conversion of Wood Land into Arable, which was the Case very much in the County of Sussex," 30 they failed to consider that increased industrialization was a major consumer of the vital oak timber. While merchant ship building consumed a large quantity of the oak, as did domestic architecture and the cooperage industry, the greatest "devourer of oaks" in the country was the iron industry, which flourished in the choicest oak regions of southern England. A great deal of the potential ship timber ended up being converted to charcoal for smelting. ${ }^{31}$ 
Having experienced Parliamentary Committee investigations in the past, the East India Company made itself extremely accommodating in this instance. Both Gabriel Snodgrass, Surveyor of Shipping for the Company, and Mr. Purling, Deputy Chairman of the Company, submitted extensive reports to the Committee. In defence of the Company's shipbuilding policies, Snodgrass informed the Commitree that merchant ship yards were able to build more ships with less timber than the King's ship yards. Unlike previous witnesses brought before the Committee, Snodgrass was able to provide detailed figures to support his argument. He informed the Committee that

[a]lthough One of the largest East India Ships carries, both Outward and Homeward-bound, as much Tonnage to Sea as a Sixty-four-Gun Ship, and Homewardbound their Cargoes are often Six Times the value of a Sixty-four-Gun Ship; yer Two of them were built for 101. 10s. per Tone each: A Sixty-Gun Ship costs, even in the Merchants Yards, 16l. 12s. 6d. per Ton; and the Difference of building each Ship is as follows, videlicet, 1 India Ship, 864 Tons, at 101. 10s. per Ton, 9,072l. Five Ships is, 45,3601 .Sixty-four-Gun Ship, 1396 Tons, at 161. 12s. 6d. per Ton, 22,759l. Two Ships is, 45,5181.

In addition, Snodgrass clarified that

[t] he above Sixty-four-Gun Ship is supposed to be built in the Merchants Yard [sic]; if the Comparison was made with a Sixty-four-Gun Ship builr in the King's yard, then it would appear that Three of the largest Ships in the Company's Service did not cost so much as building One Sixry-four-Gun Ship. ${ }^{32}$

However, he was careful to add that "I do not mean to say, it is a right Measure to build or repair King's Ships in the Merchants Yards, for, I firmly believe, this Mode has greatly raised the Price of building Merchant Ships, as well as the Price of Timber in general . . ."33 Snodgrass was informing the Committee that the King's Yards were inefficient, although he carefully avoided pointing a finger of blame when he could easily have done so. This was typical of the East India Company's defence of their shipbuilding practices. They were deferential and presented themselves as willing to aid British interests in whatever manner they could. Certainly, part of this willingness to aid the British Empire was sincere, although political necessity also figured heavily into the Company's responses and statements. 
In rebuttal to the statements that East India Company ships only lasted four voyages, Snodgrass informed the Committee thar the Company's newer ships would last five or six voyages. In addition, they were cheaper and consumed less oak in proportion to their tonnage than earlier Company ships. Furthermore, the new ships were

safer, sriffer, and much more defensible; they are more healthy for the Seamen and Recruits; are also very advantageous to the Company, in reducing their Freights, by means of the additional Surplus Tonnage brought Home on Half Freights, which enables the Company to lower the Price of their Teas, so as to prevent the smuggling thar Article from Abroad in so great a Latitude. Other Nations are so sensible of these Advantages, that they trade in much larger Bottoms than any in the Company's Employ. ${ }^{34}$

This clever statement by Snodgrass both defended the Company against the charge of only using their ships for twelve years, as well as touching on two other topics dear to British sentiment: the training of seamen and the price of tea. If, reasoned Snodgrass, the Company was able to continue building larger ships which were more economical and consumed less timber proportionately than previous ships, the health of the seamen would be better maintained. Also, as the Navy often drew its experienced seamen from those who started as merchantmen, a strong East India Company fleet would in turn strengthen the Royal Navy. ${ }^{35}$ In addition, larger ships would allow a better management of the shipping of goods, particularly tea, from the East to Britain. The byproduct would be a lowering of the price of tea, an economic benefit that would not be ignored by the public.

While Snodgrass defended the East India Company from accusations made against their shipbuilding practices, Mr. Purling, the Deputy Chairman of the Company presented the Committee with recommendations that could lighten the strain on the supplies of oak timber. The first, he informed the Committee, was for the East India Company

not to build any more Ships until their Number is reduced so as to have none lay by waiting for their Turns a whole Season; for ic is better to have rather too few than too many, as a Supply may easily be had on any Emergency; and then each Ship might make Eight Voyages in 12 or 14 Years, in the Room of 4 Voyages, and the Tonnage of Shipping by this Means reduced from 60 to 
40 Thousand Tons; this would save more than One half of the Timber now consumed: The next Method I propose is, to build Ships sufficiently large to cope with the French East India Ships, by which Means few or no Men of War would be required to protect them; consequently the Timber used for building such Men of war would be saved; and for which, in the End, they are sure to pay Four Times as much as it would cost the Company to protect themselves; for large Ships are not only more defensible, but more healthy, and consume a considerable less Number of Oak Trees, but likewise sail cheaper in Proportion than small Ships do; and a very amazing Saving to the Company also arises by Surplus Tonnage. ${ }^{36}$

All of these suggestions had a great deal of merit to them. The reduction in tonnage from 60 to 40 thousand tons was essentially what the initial timber bill requested. The only difference was that the East India Company suggested that they should voluntarily impose this reduction in tonnage, rather than have it forced upon them by an act of Parliament. The underlying fear of the Company was a loss of autonomy to Parliament. The successful passage of the timber bill could allow subsequent bills, perhaps even more damaging to the Company's autonomy, to pass that much easier. In addition, the idea of freeing Royal Navy ships from the business of protecting the merchant fleet must have had some appeal to the Admiralty. Not only would this allow the Admiralty to redirect the Fleet to other areas, but it would keep Navy ships out of the warm waters of the eastern seas which led to a more rapid deterioration of the hulls than the colder waters of, for instance, the Atlantic Ocean. Few Ships of the Line went more than twenty years without extensive repairs which would almost equal the initial cost of construction. Nelson's Victory, for example, cost $£ 63,174$ to build in 1765 . By the time she fought at Trafalgar, repairs had cost an additional $£ 188,807$, and by 1815 another $£ 119,941$ was required to maintain her. ${ }^{37}$ Admittedly, Victory was not the average ship of the Royal Navy and, consequently, costs of repair were undoubtedly higher. Still, the principle is plain: the initial cost of construction was only a small fraction of the total cost of a ship. Therefore, the longer a ship could go without requiring major repairs, the better.

All told, the East India Company effectively defended its shipbuilding practices before the Committee's investigation. Mr. Purling's suggestions appeared deferential enough and demonstrated a desire on the Company's part to help in maintaining a strong Royal Navy. Furthermore, while there was no denying that the East India Company did consume a considerable amount of oak in the construction of ships, 
the Committee discovered that Naval ships seemed to be using even more of the dwindling supplies of oak. In addition, the Committee's investigation had traced the shortage of English oak to the conversion of wooded lands to arable lands and the lack of replanting. All things considered, it did not appear that the East India Company could be made the scapegoat for the Navy's problems. Judging from the Committee's report, presented to the House of Commons in early March of 1772, the bill, which would have limited the construction of new East India Ships, should not have passed. Nonetheless, four months later, the bill became law. What went wrong?

\section{iii}

To understand the state of affairs of the East India Company in 1771, it helps to go back to the early 1760s. At the centre of many of the issues affecting the East India Company was Robert Clive, who played a leading role in the conquest of Bengal during the Seven Years War, before returning to England in 1760 for four years. With his departure, affairs in India immediately got out of hand. Internal revolts and difficulties with customs duties wrought havoc on the Company's finances and possessions. By 1764 the Mughal Emperor based in Delhi was so weak that he was incapable of implementing any agreements with the English concerning Bengal. To further complicate matters, young men in the Company's service were grossly underpaid. Consequently, they resorted to private trade, much of it in salt, betel nut, and tobacco, goods which were supposed to be privileged items of trade for the Indian merchants.

Meanwhile, the Directors and Proprietors of the Company were becoming aware that all was not well in Bengal; the Company's profits were falling while a number of its highly placed servants in India were transmitting huge private fortunes back to Britain. Now anxious, the Proprietors wanted to see Clive back in control in Bengal. Among the Directors there was less support for Clive; they had still not forgiven him for suggesting to Pict that the Crown should appropriate and manage the Company's conquests in India. ${ }^{38}$ Despite this opposition, Clive was appointed Governor and Commander-in-Chief of Bengal in 1764. The internal difficulties necessitated Clive being given a relatively free hand. He recommended to the Company's Directors that strict injunctions be put in place to prevent East India Company agents trading in salt and other privileged items. In addition, he admitted that the Company's salaries were too low for men who risked their health in India and that they had a right to compensation upon retirement. Furthermore, Clive suggested revisions in the army, administrative 
changes, a larger standing Company army, and a restriction on territorial expansions by the Company in India. ${ }^{39}$

With all of the internal difficulties in India becoming apparent to the British public, coupled with the corruption of certain high ranking Company agents who took advantage of their positions to amass huge fortunes, the call for governmental control of the affairs of the East India Company was heard. Although the Company managed to weather the storm of the early 1760 s with relatively little damage to their autonomy, by the late 1760 s affairs were once again quickly coming to a head. The various Presidencies (Madras, Bombay, and Bengal) had been borrowing money at interest in India, while at the same time drawing bills upon the India House in London. Consequently, the East India Company had to beg continually for extensions on loans so that they could honour the bills drawn against them by their agents in India. The result was a drop in the Company's credit rating. To make matters worse, the English press increasingly focused upon the Company's financial troubles, thus bringing the Directors under greater pressure to resolve the situation. Added to these difficulties facing the East India Company was the public criticism over the large amount of private trade still engaged in by Company agents stationed in India. Part of the difficulty was the British perception of India; few saw the internal strife and poor economic and social conditions. Rather, India was perceived as a land of infinite wealth from which everyone could profit. Both the Proprietors of the Company and Parliament expected their share of the Indian pie. A glimpse of what was to come was seen in 1767 when Parliament successfully demanded an indemnity of $£ 400,000$ per annum for the Crown from the East India Company.

What the issue had boiled down to was who should reap the wealth of India: the East India Company or the Crown. The Earl of Chatham's administration maintained that whatever territory an English subject acquired belonged to the State or the King, along with any revenue it generated. In opposition, the Marquis of Rockingham's party, supporters of chartered companies on general principle since the early 1760 s, sided with the Company. Charles Townshend's supporters remained quiet since they were internally divided on the issue. While this neutrality weakened the opposition's power and allowed the administration to force through its policies, the five laws of 1767 passed by Parliament to distribute the territorial revenue of the East India Company actually sidestepped the issue of whether it was the Company or the Crown that was legally entitled to the revenues. ${ }^{40}$ For $£ 400,000$ per year and a restriction of no more than $10 \%$ increases in the Proprietors' dividends yearly, the Company was able to continue more or less on its own without extensive government interference. 
Difficulties continued to plague the East India Company, however, and the administrators of Bengal were forced to draw still more bills on the Company, even though this had been forbidden by the Directors. By July of 1771 the East India Company had a deficit of $£ 1,293,000$ in London. On July 15 the Directors applied to the Bank of England for a loan of $£ 400,000$; wenty days later they applied for another $£ 300,000$. The Bank only advanced $£ 200,000$ of the second loan, and by August the situation had worsened so much that the Directors had to beg Lord North for $£ 1,000,000$, all the while maintaining that their financial croubles were only the temporary result of the ongoing wars in India and the corruption of a few agents.

With the failure of the East India Company to pay the annual indemnity to the Crown, cries for government involvement in the affairs of the Company were raised once again. In early April 1772 a Select Committee of Parliament was requested. Colonel Burgoyne proposed to

move an enquiry into the nature, state, and condition of the India company and of the British affairs in India. By the first part of the motion I mean to give powers to a committee to enquire into the constitution of the Company, into the purposes for which it was framed, and the powers with which it was invested ...41

Despite this, the East India Company was not without its allies, notably Mr. Dempster and Edmund Burke, who "spoke warmly against making any enquiry." ${ }^{2} 2$ Notwithstanding Dempster's and Burke's efforts, the Select Committee was chosen, and by the middle of 1773 the Regulating Act would be passed "for the better management of the affairs of the East India Company, as well in India as in Europe." 33 It was this atmosphere of predisposition against the Company in Parliament that would provide the backdrop for the debates over the timber bill.

iv

On March 4, 1772, almost a year to the day after it was formed, the Committee which had investigated merhods for "the more effectually securing sufficient Quantities of Oak Timber for the Use of the Royal Navy" 44 presented its report to the House of Commons. A great deal had changed in a year. When the Committee had been organized the East India Company appeared financially sound, although signs of stress were apparent to keen observers. Hal fway through the Committee's investigation, however, the Company had come apart at the seams. With the declaration of over a million Pounds deficit, there was no way the Company could maintain a semblance of financial stability. Even 
the most vocal supporters must have been worried. Consequently, by the time the Committee submitted irs report concerning the timber supply, there was a strong lobby in favour of governmental control of the East India Company. Any issue relating to the Company, even if it was not responsible for the Company's financial distress, became another topic over which Company versus Crown control could be debated. While the East India Company had presented a convincing argument in its defence, public sentiment had turned against it. No longer was the Company only responsible for justifying its shipbuilding practices; it had to defend all aspects of its management. The timber issue had become merely another point on which the Company could be attacked.

Perhaps recognizing the likelihood that Parliament would not regard Purling's suggestion (as listed in the Committee's report) that the East India Company would be willing voluntarily to reduce the tonnage of their shipping as adequate, the Directors instructed Mr. Michell, the Company's Secretary, to present to Parliament on 1 April a paper entitled "Copy of a Bye Law made by the General Court of Proprietors of East India Stock, on Wednesday the 18th of March 1772, respecting the building of Ships to be employed by the United Company of Merchants, trading to the East Indies." 45 This paper, or petition, noted that if the timber bill passed into law, the Company's rights,

derived to them, in their Corporate Capacity, by Royal Charter, will be greatly infringed; and that the Petitioners hope, the Ends of the said Bill, so far as concerns them, will appear to the House to be fully answered, from the Restraint which the Petitioners have voluntarily laid themselves under, by a Bye Law which they have lately made in a General Court of their Proprietors, to the following Effect, viz. "That no new Ship, except those now building, shall be built for the Service of this Company, until the Tonnage of all the Ships employed, or to be employed, in the Trade of this Company, on Freight to and from the East Indies, shall be reduced to 45,000 Tons, Builder's Measurement." And therefore praying that the Petitioners may be heard, by themselves or their Counsel, against so much of the said Bill, as relates to the Shipping to be employed in the Commerce of the Petitioners; and that the same may not pass into a Law. ${ }^{46}$

The presentation of this petition to Parliament demonstrates how the issue had drifted away from the use of timber in ship construction 
to a challenge of the Company's charter. There was no mention of the Company's charter, its corporate capacity, nor the commercial interests of the Proprietors in the Committee's report. Now, the East India Company suddenly brought attention to these points. It is the reference to the Company's charter that is the key element demonstrating that the timber bill had become part of the greater battle over Company versus Crown control of trade and territory in India. Indeed, there was an even larger issue involved: the Constitution of Britain. Burgoyne told the Commons on 13 April, less than two weeks after he had called for a Select Committee into the East India Company's affairs, that many believed that if the affairs of the Company were thrown "into the hands of the crown... the death-blow to the constitution is most to be apprehended ..." "47 That is, some feared that Crown control over a chartered company would be the first step in the overthrow of the British Constitution and initiate a return to an absolute monarchy. Thus, affairs concerning the East India Company mirrored the greater Constiturional issues facing Britain as a whole. As Edmund Burke wrote to a friend on 30 Sepcember 1772,

[r] he affairs of the Company are at once flourishing, and in the greatest confusion and the greatest danger - just like the affairs of this country. Our parliamentary proceedings have added to the confusion, and our subsequent neglects have completed it . . . ${ }^{48}$

Another Constitutional crisis was in the making.

The debate over the timber bill on 9 April is further evidence that the bill was being used as a soapbox from which Members of Parliament could express their opinions of government involvement in the affairs of the East India Company. It was noted that the bye-law passed by the Company would accomplish the same goal as the bill: reduction of the tonnage of East India Company shipping from 60,000 tons to 45,000 tons. Voluntarily passing the bye-law, reasoned the Company's defenders, had the effect of altering the mandate of the timber bill to "make it simply an Act to confirm that bye-law." 49

Despite such arguments and the Committee's report, the Admiralty was still in favour of the bill, declaring that it was

essentially necessary to promote the growth of timber for the royal navy, that it should not be directed to other purposes: that the consumption in the East-India ships was prodigious, as they lasted seldom more than three voyages...50 
This was a predictable statement by those who wished to see the bill passed regardless of the information presented by the Committee. For example, while the Admiralty advocated the promotion of new forests, it continued to hold to the belief that it was the East India Company's shipbuilding practices that were primarily responsible for the lack of timber, despite the Committee's declaration that an equal or greater responsibility should lie with the Royal Navy's shipbuilding policies. In addition, the Admiralty's claim that Company ships only lasted three voyages found no support at all in the Committee's report. Indeed, this was a blatant distegard for the findings of the Committee, as four voyages had been the minimum number mentioned in the report. The proponents of the bill also stated that "it plainly appeared by the byelaw, that it was the opinion of the Directors that Sulla made himself master of the liberries of Rome, after he had conquered the East." ${ }^{51}$ This Classical allusion drew a similarity between the Directors of the East India Company and the much despised Roman emperor Sulla, who, after Eastern conquests, squandered the wealth of the Roman Empire for his own personal gratification. Herein lies an explanation for why there appears to have been such a blatant disregard for the information presented in the Committee's report. The supply of timber was no longer the issue. It had become a debate over the conquests of the East India Company in India and the perceived liberties the Company was taking with its charter at the expense of Britain.

Similarly, the Company's defenders were motivated, not by maintaining a sufficient supply of timber for the Royal Navy, but by the preservation of the Company's independence from government control. They argued that the timer bill was "full of the most dangerous doctrines ..." Indeed, if it passed, there would be an "intolerable burthen on commerce, which ought to find its own value, and must not be cramped in its progress..." In addition, they argued that it was not only the progress of the East India Company that would be impeded, but of all merchants based in England. For while the "Bill would indeed preserve to the navy all the large timber now growing," it would destroy the sanctity of private enterprise, for there would no longer be as large a market for timber merchants. Finally, the Directors of the Company "had indeed made a bye-law, but future necessity might make that law inconvenient, and, commerce increasing, force a repeal of it; but, if once passed into law, would with difficulty be again obtained." 52 Those defending the Company were no longer doing so on the basis of the evidence presented to the Committee concerning the more efficient building practices of the private shipyards and lower costs and use of less timber for East India merchant ships. Instead, they were making emotional appeals concerning the traditional rights of English mer- 
chants to profit by their trade withour hindrance from the government.

Unfortunately for the East India Company, events (as well as years of mismanagement) conspired against it. The massive debts of the previous summer could not be forgotten or ignored. Despite the Directors' optimistic suggestion that commerce with India could increase in the future and become vastly profitable once again, it appears that most Members of Parliament, upon examining the trends of the last decade, could not accept this hopeful speculation. The tide of public opinion had turned against the Company. Consequently, the timber bill passed in the House of Commons on 15 May 1772, 94 to 46. It was only one in a series of new bills, culminating in the Regulating Act of 1773 , that would serve to limit the Company's powers and make it subservient to Parliament.

With respect to the timber bill, the East India Company was a victim of poor timing and circumstance. If the bill had been proposed five years earlier it seems unlikely that it would have passed into law. The Lords of the Admiralty, while looking for a convenient scapegoat for their dockyard problems, would have been faced with the realization that reorganization and streamlining of the Royal Navy's shipbuilding practices was in order. For while the East India Company's shipbuilding was partially responsible for the lack of oak timber, as was the construction and repair of ships in the Royal Navy, the Committee report demonstrated that poor reforestation programs, an increase in arable land, and the growth of the English barrel industry were more deserving of blame. The Company's representatives presented compelling evidence that their ships were not only more economical but also used less timber, proportionately, than earlier ships. When coupled with the Company's willingness to impose limitations on itself concerning the tonnage of its ships, there was no reason for the timber bill to be passed into law except that it had become part of the greater debate in which the control of the East India Company by its Directors and Proprietors or by the Crown was the issue.

The fact that the Company was experiencing financial devastation, most of it brought upon itself over the years by mismanagement, poor trading practices, and territorial expansion, could not be ignored. By April of 1772, it was clear that major revisions to the Company would be required if it was ever to be profirable again. While the timber bill had nothing to do with such matters, once the financial troubles of the Company became readily apparent, the bill became merely another venue for the debate over Company versus Crown control of India. 
venue for the debate over Company versus Crown control of India.

The Company's defenders were fond of quoting Queen Anne's Charter which stated that the "merchants of the East Indies and their successors may be the better encouraged to proceed in their trade, and to make lasting settlement for the support and maintenance thereof." 53 They claimed that this rendered their territorial rights and leadership in India perpetual and made no mention of sharing any revenues derived from trade with the Crown. However, Queen Anne's Charter was granted to the Company long before it declared a $£ 1,293,000$ debt. That debt, following the crash in the Company's stock in 1769 , could not have inspired confidence in the Directors' policies and leadership of the Company. As the Company had apparently become incapable of administering its financial empire, perhaps it was time for Parliament to step in and oversee the managing of East Indian affairs.

For, indeed, the Company's affairs in India were no longer strictly commercial in nature. Rather, it had strayed into the realm of political operations so that the Company's Directors in London appeared almost as the de facto rulers of India. Years later, after Edmund Burke had ceased to be a defender of the East India Company, he described it as one that "did not seem to be merely a Company formed for the extension of the British commerce, but in reality a delegation of the whole power and sovereignty of this kingdom into the East." ${ }^{54}$ Governmental control of a strictly commercial corporation would have threatened the Constitution. However, with the political aspect of the East India Company made apparent, the Regulating Act could be justified as an attempt to preserve the Company's commercial interests mostly untouched, while allowing Parliament to oversee the governing of the Company's territorial possessions in India. ${ }^{55}$ And though the timber bill had not begun that conversion, it served as another stepping stone in the path to the Regulating Act and the transformation of the East India Company from a commercial corporation to one subordinate to Parliament both financially and politically. 


\section{NOTES}

I wish to thank P. Lawson for valuable discussions concerning eighteenth century Britain. I also wish to acknowledge P. Lawson and R.E. Snyder for their careful reading of the manuscript.

1 For a recent example, see W.M. Elofson, "The Rockingham Whigs in Transition: the East India Company Issue 1772-1773," English Historical Review 104 (1989), 947-974.

${ }^{2}$ K.N. Chaudhuri's The Trading World of Asia and the English East India Company 1600-1760 (Cambridge, 1978) is the primary source concerning the early period of the Company. C.H. Philips, in The East India Company 1784-1834(Manchester, 1961), deals with the later years. H.V. Bowen's Revenue and Reform: the Indian Problem in British Politics 1757-1773 (Cambridge, 1991) is an interesting and valuable reappraisal of the Company's affairs with respect to British politics in the years preceding the American Revolurion.

${ }^{3}$ None of the major works on the East India Company pay more than passing notice to the issues of shipping and the timber required for maintaining the Company's fleet. Chaudhuri briefly mentions that traditional Asian shipping relied on the teak forests of Malabar, "though opposition of shipping interests in England prevented the Asian-built vessels from being used in direcr trade with Europe" (Trading World 202). Likewise, Philips refers only in a footnote to an incident in 1801 in which "The Admiralty encouraged the Company to build small ships because timber was scare" ( East India Company, 113). With the exception of these fleeting references very little has been written relating to the importance of the East India Company's shipping interests and its effect on the interests of the Royal Navy.

${ }^{4}$ Unired Kingdom, House of Commons Sessional Papers, 1772, 3135, "A Bill for the More Effectually Securing Sufficient Quantities of Oak Timber for the Use of the Royal Navy"

${ }^{5}$ Ibid.

${ }^{6} \mathrm{~J}$. Debrert, ed., The History, Debates, and Proceedings of Both Houses of Parliament of Great Britain, From the Year 1743 to the Year 1774, vol. 6 (London, 1792), 84

7 The Journals of the House of Commons, 1770-1772, vol. 33 (London, 1804), 245 ${ }^{8}$ R.J.S. Hoffman, Edmund Burke, New York Agent (Philadelphia, 1956), 441 ${ }^{9}$ United Kingdom, H. of C. Sessional Papers, 1771, 3114, "A Report from the Commitree, Appointed (Upon the 11 th Day of March, 1771) to Consider How His Majesty's Navy May Be Better Supplied With Timber," 175-76

$10 \mathrm{~J}$. Debretr, ed., The History, Debates, and Proceedings of Both Houses of Parliament of Great Britain, From the Year 1743 to the Year 1774, vol. 4 (London, 1792), 216

" O.A.R. Murray, "The Admiralty, Part VI," The Mariner's Mirror 24 (1938), 330

${ }^{12}$ Ibid., 330

${ }^{13}$ R.G. Albion, "The Timber Problem of the Royal Navy, 1652-1862," The Mariner's Mirror 38 (1952), 4 
${ }^{14}$ Ibid., 4

is Murray, "Admiralty, Part VI," 330

16 "Report from the Committee," 176

${ }^{17}$ Ibid., 179, 181

${ }^{18}$ Albion, "Timber Problem of the Royal Navy," 7

${ }^{19}$ Ibid., 9

${ }^{20}$ Ibid., 8

21 "Report from the Committee," 179

22 Ibid., 179

${ }^{23}$ Ibid., 177

24 Ibid., 177

${ }^{25}$ Ibid., 183

${ }^{26}$ Ibid., 196

${ }^{27}$ Ibid., 198

${ }^{28}$ Ibid., 196

${ }^{29}$ Albion, "Timber Problem of the Royal Navy," 16

30 "Report from the Committee," 183

${ }^{31}$ Albion, "Timber Problem of the Royal Navy," 15

32 "Report from the Committee," 203

${ }^{33}$ Ibid., 202

${ }^{34}$ Ibid., 203

35 The Grand Banks fishing fleets were well known as the training grounds for the seamen of the Royal Navy. However, renowned Naval officers were trained on other merchant ships. The celebrated Captain James Cook, for example, received his early training on colliers before enlisting with the Royal Navy.

36 "Report from the Committee," 206-207

${ }^{37}$ Albion, "Timber Problem of the Royal Navy," 15

${ }^{38} \mathrm{~J} . \mathrm{A}$. Williamson, A Short History of British Expansion: The Old Colonial Empire (London, 1959), 410

${ }^{39}$ Ibid., 411

${ }^{40}$ T. Desai, The East India Company: A Brief Survey From 1599-1857(New Delhi, 1984), 187

${ }^{41}$ The Parliamentary History of England, vol. 17 (London, 1813), 456

42 Ibid., 461

43 United Kingdom, H. of C. Sessional Papers, 1773, 3184, "A Bill [With Amendments] for Establishing Certain Regulations for the Better Management of the Affairs of the East India Company, as Well in India as in Europe," 89

4 Journals of the House of Commons, 1770-1772, 553

${ }^{45}$ Ibid., 643

46 Ibid., 656

47 Parliamentary History of England, 458

${ }^{48}$ Cited in Hoffman, Edmund Burke, 536-537 
${ }^{49}$ Debrett, ed., History, Debates, and Proceedings of Both Houses of Parliament, 250 ${ }^{50}$ Ibid., 251

${ }^{51}$ lbid.

52 Ibid.

53 Cited in Desai, East India Company, 189

${ }^{54}$ Cited in P. J. Griffiths, A Licence to Trade: the History of English Chartered Companies (London, 1974), 99

ss Ibid., 99 